\title{
Human Resource Development Climate and Employee Commitment in Recapitalized Nigerian Banks
}

\author{
Akinyemi Benjamin \\ Department of Human Resource Management, School of Finance and Banking \\ P.O. Box 1514, Kigali, Rwanda \\ Tel: 250-783-468-279 E-mail: akinyemi.ben@gmail.com \\ Iornem David \\ Institute of Management Consultants \\ 18/19 Ahmadu Bello Way, P.O Box 9194, Kaduna, Nigeria \\ Tel: 234-703-080-2998 E-mail: openlearning3000@yahoo.com
}

Received: August 12, 2011

Accepted: September 5, 2011

Published: March 1, 2012

doi:10.5539/ijbm.v7n5p91

URL: http://dx.doi.org/10.5539/ijbm.v7n5p91

\begin{abstract}
This study was undertaken to measure employees' perception of their affective, normative and continuance commitment in relation to the prevailing developmental climate within the Nigerian banking sector in the context of reforms and change. The sample comprised 303 employees of selected recapitalized Nigerian commercial banks. Data for the study were gathered through self-administered questionnaire. The data collected were subjected to appropriate statistical analysis using the Statistical Package for Social Scientists (SPSS) to produce the mean, standard deviation, variance and Pearson product moment correlation coefficient of variables. The formulated hypothesis was tested at 0.01 level of significance and the result of statistical analysis indicated the existence of positive relationship between HRD climate and Organizational Commitment.

Keywords: Human Resource Development climate, Affective, Continuance and normative commitment, Training, Nigerian commercial banks

\section{Introduction}

Globally, the $21^{\text {st }}$ century economic landscape has become volatile and unstable. Thus, firms must continue to reinvent themselves in order to maintain the competitive edge. The current rise in knowledge work, as well as reduced product life cycle time, workforce diversity, flatter, leaner and more participative organizations have put priority on human capital as the major strategic asset of organizations that strive for sustainable competitive advantage (Akinyemi, 2007; Becker, Huselid, \& Ulrich, 2001; Kearns, 2004; Mercer, 2003; Pfeffer, 1998; Torraco \& Swanson, 1996; Ulrich, 1998; Wright, 1999). It is in the interest of organizations to constantly look for opportunities to acquire and apply actionable knowledge, expertise, and imagination to satisfy constantly changing customer needs and demands. For the Nigerian banking industry to cope with mounting local and global competitive pressures, the need for human capital transformation is imperative. Attention should be given to human resource development with a view to filling existing skill gaps so as to meet current and anticipated future organizational needs (Akinyemi, 2008).

In view of the foregoing, investigating the impact of HRD climate on employee attitude in the banking industry is significant. The Nigerian banking sector "plays the important role of promoting economic growth and development through the process of financial intermediation" (Sanusi, 2011). Currently, the sector is undergoing series of reforms that have drastically reduced its number and with serious implications for human resources management. For instance, the reconsolidation exercise of the year 2005 shrinked the number of commercial banks in Nigeria to twenty five (25) from eighty nine (89) through mergers and acquisitions. This led to drastic reduction in the number of employees as the commercial banks embarked on downsizing. The banks also had to grapple with the challenge of attracting, engaging, developing and retaining talents. The dynamic nature of the banking industry as well as its relevance in promoting economic growth and development make it an ideal sector
\end{abstract}


to focus on in this research. In addition, there is paucity of empirical research linking developmental climate to employee attitude in the Nigerian banking industry.

The results of the study promise to be of immense benefit to banks' management as they reveal the prevailing attitude of banks' employees towards organisational developmental climate. Management is, therefore, able to understand the perceptions of employees and resolve any form of existing or impending problems that are capable of undermining the overall goals or objectives of change.

\section{Background}

Human Resource Development (HRD) has been defined in various ways. Chalofsky (1992) defines it as "the study and practice of increasing the learning capacity of individuals, groups, collectives, and organizations through the development and application of learning-based interventions for the purpose of optimizing human and organizational growth and effectiveness." As a function within an organisation, it "plays a principal role in enhancing the long-term sustainability of organizations and has the potential to help cultivate organizations that positively influence individuals, communities, society, and the environment" (Hatcher, 1999). According to McLean and McLean (2001:10) HRD is "any process or activity that, either initially or over the long term, has the potential to develop ... work-based knowledge, expertise, productivity and satisfaction, whether for personal or group/team gain, or for the benefit of an organization, community, nation, or, ultimately, the whole of humanity."

Stating the major purpose of HRD, Sampson (2005) stressed that it "is to change behaviour through training and other incentives." McKenna (2000) is of the view that developing employees' skills on the job, including interactive skill results in favourable impact on the level of morale, which, in turn, enhances commitment to the organization. As a function within an organization, HRD provides opportunities for an individual worker to improve current and future job performance, while simultaneously best utilizing human capital in order to improve the efficiency of the organization itself. Ideally, well-developed and well-implemented HRD systems are integral to the company's strategic plan and benefit both the employee and the company. In essence, HRD is a potential tool for individual, group and organisational change and transformation. It therefore needs a conducive environment or climate for it to thrive and achieve intended goal.

HRD comprises of developmental functions such as formal and informal training, career development, performance management and development, organizational development, coaching and mentoring. The focus of HRD is on developing the most superior workforce so that the organization and individual employees can accomplish their work goals in service to customers. Stating the major purpose of HRD, Sampson (2005) stressed that it "is to change behaviour through training and other incentives." McKenna (2000) is of the view that developing employees' skills on the job, including interactive skill results in favourable impact on the level of morale, which, in turn, enhances commitment to the organization.

\subsection{Human Resource Development Climate}

Webster's dictionary (1992) defines climate as: (1) the prevailing or average weather conditions of a place, as determined by the temperature and meteorological changes over a period of years; (2) any prevailing conditions affecting life, activity, etc.; and (3) a region considered with reference to the kind of weather prevailing there. In Organization context, climate consists of the prevailing conditions within the organization that affect the life of employees and the activities within the organization (Smith, 1988). Reichers \& Schneider (1990:22) define organizational climate as the "shared perceptions of organizational policies, practices, and procedures, both formal and informal." It is also defined as "a characteristic of an organization which . . . embodies members' collective perceptions about their organization with respect to such dimensions as autonomy, trust, cohesiveness, support, recognition, innovation and fairness ..." (Moran and Volkwein, 1992:20). Climate is also "the relatively persistent set of perceptions held by organization members concerning the characteristics and quality of organizational culture (French et al. 1985).

HRD climate is an integral part of the prevailing general organizational climate which may include characteristics such as: importance given to human resource, openness of communication, encouragement given to risk-taking and experimentation, feedback given to employees to make them aware of their strengths and weaknesses, a general climate of trust, faith in employee's capabilities, employees' tendency to assist and collaborate with each other, team spirit, tendency to discourage stereotypes and favouritism, and supportive personal policies and practices. For a positive HRD climate to prevail within an organization, it must be built on eight important culture characteristics identified by Rao and Abraham (1990). These characteristics are: Openness, Confrontation, Trust, Autonomy, Proaction, Authenticity and Collaboration (OCTAPAC). However, organizations differ in the extent to which they are able to align with these characteristics. 
Schein (1992:231) suggests that in newer organisations, organisational climate reflects the assumptions held by its leadership. In the organisation's latter life, however, cultural assumptions tend to dominate the climate. Such assumptions affect the climate via 6 primary embedding mechanisms such as:

- What leaders pay attention to, measure, and control on a regular basis;

- How leaders react to critical incidents and organizational crises;

- Observed criteria by which leaders allocate scarce resources;

- Deliberate role modeling, teaching, and coaching;

- Observed criteria by which leaders allocate rewards and status;

- Observed criteria by which leaders recruit, select, promote, retire, and excommunicate organizational members.

\subsection{Organizational Commitment}

Organizational commitment, in general terms, is an employee's voluntary bonding to an employer or organisation. It connotes support for, practical identification with and devotion, loyalty and submission to the organization's ideals, mission or vision. Committed employees are also identified by their preparedness to exhibit self or personal sacrifice and are sometimes seen as putting the interest of the organization ahead of theirs or any others'. They are not just part of the organization but are agglutinated to the organization for as long as their commitment lasts.

Organizational commitment has been defined as an attitude or an orientation which links the identity of the person to the organization, a process by which the goals of the organization and those of the individual become congruent, an involvement with a particular organization, the perceived rewards associated with continued participation in an organization, the costs associated with leaving, and normative pressures to act in a way which meets organizational goals (Meyer \& Allen, 1997). The process of becoming committed to an organization involves internalizing the values and goals of the organization, a willingness to help the organization achieve its goals, and the desire to remain part of the organization (Morgan \& Hunt, 1994; Mowday, Steers, \& Porter, 1982).

Allen and Meyer (1997) have identified three forms of commitment: Affective, Continuance and Normative Commitment. Affective Commitment essentially concerns the person's emotional attachment to, identification with, and involvement in, the organization. It describes the emotional attachment a person feels for the organization and is defined as the degree to which an individual is psychologically attached to an organization through loyalty, affection, belongingness. It has to do with the to stay with the organization based on the costs of leaving or a sense that available comparable alternatives are limited. Continuance Commitment is based on the costs and risks that the employee associates with leaving his or her current organization while Normative Commitment introduces a moral dimension being based on the employee's feeling of obligation and responsibility to remain with his or her organization. It is, however, essential to state that these commitment components are not mutually exclusive as employees may experience varying levels of commitment components.

\section{Empirical Review}

Researchers have identified certain dimensions of organizational climate as relating to organisational commitment. For instance, dimensions such as autonomy (Wallace et al., 1996), supervisor support (Benson, 1996) and cohesiveness (Buchanan, 1974) relate positively to organizational commitment. Also, Steers (1977) found a relationship between the autonomy and trust dimensions of organizational climate and commitment while Loiu (1995) found that trust is associated with other organizational activities such as organizational change and development (Golembiewski, 1986), and organizational effectiveness (Culbert and McDonough, 1986). Fink and Chen (1995) also found that organizational climate was positive when organizational commitment was high. In another study conducted by Iverson, et al. (1995:12) it was found "that organizational commitment and trust appeared to be significant determinants of performance".

Organizational commitment has also been found to relate to human resource development functions. Focussing on the relationship between formal workplace training and organizational commitment, Bartlett, 2001; Kontoghiorghes \& Bryant, 2001; McMurray \& Dorai, 2001 have indicated that formal training enhances employees' organizational commitment. Other researchers such as Martin and O'Laughlin,1984; Mathiew, 1991; Sharma, 1989 had also found a correlation between training and organizational commitment. Organizations that offer employees a relative high degree of development opportunities and internal career possibilities were also found to have elicited higher level of performance and commitment (Tsui et al. (1977). Availability of personal 
development opportunities has also been reported to have a positive effect on perceived rationalism of the employment relation, which is also said to have accounted for higher levels of commitment and job satisfaction. In organizations that offer training opportunities, employee commitment and citizenship behaviour are found to be higher than in organizations that do not offer the same. In contrast, however, Dereli (2006) found no significant relationship between normative commitment and human resource development programs. Granrose and Baccili (2006) also found that violation of perceived training obligations result in reduced organizational commitment and increased intentions to leave the organization.

Empirical studies have confirmed the fact that an open culture, a learning climate and provision of training and development opportunities are important for today's workforce. For example, Gründemann et al. (2005) argue that organizations that differentiate themselves by offering individualized and customized employment relations, an open and respectful culture and abundant development opportunities are the employers of choice of professional workers. In a study by Lowry et al. (2002) there is an indications that the availability and adequacy of training affected job satisfaction and commitment levels of employees. Researches (Caldwell et al. 1990, Morris et al., 1993) have also shown the effect of availability of training on employee commitment. Studies (Brinkerhoff and Montensio, 1995; Huczynski and Lewis, 1980; Michalak, 1981; Tracey et al., 1995) showed the influence of the immediate supervisor in encouraging or discouraging usage of training.

Cheung (2000) and O'Driscoll and Randall (1999) also predicted that support for training from senior staff and from colleagues is positively associated with organizational commitment. Tannenbaum et al. (1991) found that naval recruits who participated in an 8-week training held higher levels of affective commitment than before the training. Visser and vand der Sluis (2006) also reported that there are significant relations between organizational support for training and personal development and work attitudes like affective commitment and normative commitment. Montesino (2002) suggested that a company needs to pay close attention to linking its training programs with the corporation's strategic direction in a way that is explicit, clearly communicated and evident to trainees.

\section{Methodology}

The survey research design method was used in this study. It involves the use of questionnaire in collecting data from the respondents. A total of 303 employees belonging to eight recapitalized banks located in Soutwestern Nigeria responded to a questionnaire which measured the following variables: Human Resource Development Climate, Affective, Normative and Continuance Commitment. The recapitalized banks were commercial banks that have fufilled a mandatory minimum capital base of 25 billion Naira - US\$200 million.

\subsection{Instruments}

The research instruments used in the study are: HRD climate survey Questionnaire and Organisational Commitment Questionnaire. The HRD climate survey questionnaire was developed by T.V. Rao and E. Abraham at the XLRI Center for HRD. This 38-item instrument is widely being used to survey the organisational HRD climate. It is a 38-item questionnaire that assesses an organisation's the general climate, prevailing culture as well as the implementation of HRD mechanism or policies. Organisational commitment was measured using Meyer and Allen's (1997) 23-item organisational commitment scale. The instrument measured the three main components of commitment: affective ( 8 items), normative ( 6 items) and continuance commitment (9 items). In this study, the Cronbach's alpha was $.96,87, .84$, and .77 for HRDC, affective, continuance and normative commitment respectively.

\subsection{Hypothesis}

The hypothesis tested in this study is stated thus:

$\mathrm{H}^{1} \quad$ There is a significant relationship between HRD Climate and Organizational (Affective, Continuance and Normative) commitment.

\subsection{Analysis of Data}

Data analysis was carried out by using Statistical Package for Social Scientists (SPSS) for Windows. To test the hypothesis, the mean, variance, standard deviation and Pearson Product Moment Correlation Coefficient of all Variables were calculated. To evaluate the reliability of the results the $R^{2}$ is reported. $R^{2}$ is the square of the Pearson product moment correlation coefficient through data points in HRD (independent values $-x$ ) and AC, CC, NC (dependent values $-y$ ). The $R^{2}$ value can be interpreted as the proportion of the variance in $y$ attributable to the variance in $x$. As an indicator from 0 to 1 , it is most reliable when its value is at or near 1 . 


\section{Results and Discussion}

Table 1 shows information about the descriptive statistics of the data used in the analysis, see Table 1 . The correlation between $\mathrm{HRD}$ and $\mathrm{AC}, \mathrm{CC}$ and $\mathrm{NC}$ was calculated on one hand, and the correlation within the dependent variables: $\mathrm{AC}$ and $\mathrm{CC}, \mathrm{AC}$ and $\mathrm{NC}, \mathrm{CC}$ and $\mathrm{NC}$ was also calculated. It is imperative to know both how HRD climate influences organizational commitment (comprising of $\mathrm{AC}, \mathrm{CC}$ and $\mathrm{NC}$ ) and how the different types of commitment influence each other in recapitalized Nigerian banks (see Table 1). This table (1) also shows the results of the Pearson correlation of variables.

\section{Insert Table 1 about here}

Figure 1 shows that there is a high positive correlation between HRD and AC (0.75) except for CC and NC which are 0.59 and 0.69 respectively. From Figure 1, $r$ values between the different types of commitment are as follows: for $\mathrm{AC}, \mathrm{CC}$ and $\mathrm{NC}$ range from 0.71 to 0.52 . The r-squared values in Table 1 reveal that the HRD climate is better explained by the AC (r-squared $=0.55)$ than either CC $(r-s q u a r e d=0.31)$ or $\mathrm{NC}(\mathrm{r}$-squared $=$ 0.45 ). That is $55 \%, 31 \%$ and $45 \%$ of the variance in $\mathrm{AC}, \mathrm{CC}$ and $\mathrm{NC}$ (organizational commitment) values can be explained by variation in the HRD climate.

Insert Figure 1 about here

Results from data analysis clearly show that a human resource development climate influences Affective Commitment more than it does for Continuance and Normative Commitment. It is also observed that although HRD climate positive correlates with both Normative and Continuance Commitment, the relationship is not so strong. Affective Commitment is an employee's psychological attachment to the organization. It is, therefore, observed that those who perceive a positive human resource development within an organization are more likely to have higher feelings of affective commitment.

This finding agrees with previous findings that link commitment to organisational commitment (Purang, 2008) autonomy (Wallace et al., 1996), supervisor support (Benson, 1996) cohesiveness (Buchanan, 1974), formal workplace training (Bartlett, 2001; Kontoghiorghes and Bryant, 2001; McMurray and Dorai, 2001; Caldwell et al. 1990, Morris et al., 1993), open culture, a learning climate and organizational support for training and personal development (Visser and van der Sluis, 2006; Gründemann et al., 2005).

\section{Study Limitations}

This study, carried out in a non-Western culture environment, used a tested and reliable Western employee commitment scale items. Its validity and reliability has made it attractive to researchers but there are reservations about its applicability in non-Western culture (Ogba, 2008; Cheng and Stockdale, 2003; Lee et al., 2001; Gautam et al., 2001; Wasti, 2002). Similar studies tend to suggest a number of inconsistencies with the scale items' measurability and fitness. Therefore, further studies are needed using non-Western culture instruments to measure employees' attitudinal and behavioural responses such as affective, continuance and normative commitment.

\section{Conclusion and Practical Implications}

The focus of this paper was to determine the influence of organizations' HRD Climate on employees' attitude organizational commitment. In view of the results from data analysis it is evident that HRD climate actually positively correlates with employee commitment, especially the affective component.

This research suggests that a positive HRD climate has a strong influence on the level of affective commitment. Findings from the study have some practical implications. The findings can be used by managers and scholars in general and HR practitioners in particular to build a positive or congenial developmental environment that promotes employee high commitment for enhanced individual and organisational performance and productivity. It is, therefore, suggested that banks operating in Nigeria should foster employee commitment by embedding positive HRD culture of Openness, Confrontation, Trust, Autonomy, Proaction, Authenticity and Collaboration (OCTAPAC) into their organisational culture.

\section{References}

Akinyemi, B.O. (2007). Organizational Knowledge Management in the New Economy. Management Journal, Vol. 43, 24-32.

Akinyemi, B.O. (2008). Impact of Human Resource Development Climate on Employee Commitment, Citizenship Behaviour and Turnover Intentions in Selected Nigerian Banks. Unpublished PhD dissertation submitted to the Graduate Committee, Commonwealth Open University, British Virgin Islands, UK. 
Bartlett, K. R. (2001). The Relationship between Training and Organizational Commitment: A study in the Health Care Field. Human Resource Development Quarterly, 12, 335-352. http://dx.doi.org/10.1002/hrdq.1001

Becker, B., Huselid, M., \& Ulrich, D. (2001). HR as a Strategic Partner: The Measurement Challenge. In The HR Scorecard: Linking People, Strategy, and Practice, pp. 1-26. Boston: Harvard Business School Press.

Benson, J. (1996). Dual Commitment: Contract Workers in Australian Manufacturing Enterprises. Working Paper 101. Melbourne: University of Melbourne.

Brinkerhoff, R.O., \& Montesino, M.U. (1995). Partnerships for Training transfer: Lessons from a corporate study. Human Resource Development Quarterly, 6, 263-274. http://dx.doi.org/10.1002/hrdq.3920060305

Buchanan, B. (1974). Building Organizational Commitment: The Socialization of Managers in Work Organizations. Administrative Science Quarterly, 19, 533-546. http://dx.doi.org/10.2307/2391809

Caldwell, D.F., Chatman, J.A., \& O'Reilly, C.A. (1990). Building Organizational Commitment: A Multi-firm Study. Journal of Occupational Psychology, 63, 245-261. http://dx.doi.org/10.1111/j.2044-8325.1990.tb00525.x

Chalofsky, N. (1992). A Unifying Definition for the Human Resource Development Profession. Human Resource Development Quarterly, 3, 175-182. http://dx.doi.org/10.1002/hrdq.3920030208

Cheng, Y., \& Stockdale, M.S. (2003). The validity of the three-component model of organisational commitment in a Chinese context. Journal of Vocational Behaviour, 62, 465-89. http://dx.doi.org/10.1016/S0001-8791(02)00063-5

Cheung, C.K. (2000). Commitment to the Organization in Exchange for Support from the Organization. Social Behavior and Personality, 28, 125-140. http://dx.doi.org/10.2224/sbp.2000.28.2.125

Culbert, S.A., \& McDonough, J.J. (1986). Organisational Trust Effectiveness: The Politics of Trust and Organisational Empowerment. Public Administration Quarterly, 18, 177-178.

Dereli, B. (2006). The Effect of Human Resource Development on the Organizational Commitment. e-Proceedings of the $2^{\text {nd }}$ International Conference on Business, Management and Economics, Altinyunus Resort, Hotel/Convention Center, Cesme, Izmir-Turkey, 15-18 June, 2006.

Fink, E.L., \& Chen, S.S. (1995). A Galileo Analysis of High Performance: Some Good News and Some Bad News about Merit Pay. Review of Public Personnel Administration, 7, 9-27.

French, W.L., Kast, F.E., \& Rosenzweig, J.E. (1985). Understanding Human Behaviour in Organizations. Harper \& Row, New York.

Gautam, T., Dick, R., \& Wagner, U. (2001). Organisational commitment in Nepalese settings. Asian Journal of Social Psychology, 4, 239-48. http://dx.doi.org/10.1111/1467-839X.00088

Golembiewski, R.T. (1986). OD Perspectives on High Performance: Some good new and some bad news about merit pay. Review of Public Personnel Administration, 7, 9-27. http://dx.doi.org/10.1177/0734371X8600700102

Gründermann, R., Goudswaard, A., \& Van Sloten, G. (2005). Goed werkgeverschap. Zalthbommel: Uitgeverji Thema.

Hatcher, T. (1999). Reorienting the Theoretical Foundations of Human Resource Development: Building a Sustainable Profession and Society. Academy of Human Resource Development 1996 Conference Proceedings, Arlington, VA, p. 7-1.

Huczynski, A.A., \& Lewis, J.W. (1980). An Empirical Study into the Learning Transfer Process in Management Training. Journal of Management Studies, 17, 277-240. http://dx.doi.org/10.1111/j.1467-6486.1980.tb00086.x

Iverson, R.D., McLeod, C.S., \& Erwin, P.J. (1995). Employee Commitment and Trust: Implications for Effective Marketing. Working paper no 92. Parkville, Vic: Department of Management \& Industrial Relations, university of Melborne.

Kearns, P. (2004). How Strategic are you? The Six “killer" Questions”. Strategic HR Review, 3, 20-23.

Kontoghiorghes, C., \& Bryant, N. (2001). Exploring Organization Commitment in a Non-profit Service Organization, In O. A. Aliaga (Ed.), Proceedings of the Academy of Human Resource Development (pp.1056-1063). Baton Rouge, LA: AHRD.

Lee, K., Allen, N.J., Meyer, J.P., and Rhee, Y. (2001). The three-component model of organisational commitment: an application to South Korea. Applied Psychology: An International Review, 50, 596-614.

Lowry, D.S., Simon, A., \& Kimberley, N. (2002). Toward Improved Employment Relations Practices of Casual 
Employees in the New South Wales Registered Clubs Industry. Human Resource Development Quarterly, 13, 53-70. http://dx.doi.org/10.1002/hrdq.1013

Martin \& O'Laughlin. (1984). Predictors of organisational commitment, The Study of Part-Time Army Reservists. Journal of Vocational Behaviour, 25, 270-283. http://dx.doi.org/10.1016/0001-8791(84)90050-2

McKenna, E. (2000). Business Psychology and Organizational Behaviour, (3rd Edition.) Philadelphia Psychological Press.

McLean, G. N., \& McLean, L. D. (2001). If we can't Define HRD in one Country, how can we Define it in an International Context?. Human Resource Development International, 4, 313-326. http://dx.doi.org/10.1080/13678860110059339

McMurray, A. J., \& Dorai, R. (2001). The Rrelationship Between Workplace Training and Organizational Commitment in Australian Organizational Settings: A Preliminary Analysis, A Paper Presented at the Academy of Human Resource Development Annual Conference, Oklahoma City, OK.

Mercer Human Resource Consulting. (2003). Building a human capital strategy. Strategic HR Review, 2, 12-16.

Meyer, J. P., \& Allen, N. J. (1997). Commitment in the workplace. Thousand Oaks. Ca. Sage Publications.

Michalak, D. F. (1981). The Neglected Hall of Training. Training and Development Journal, 35, 22-28.

Montesino, M.U. (2002). Strategic Alignment of Training, Transfer-enhancing Behaviors, and Training Usage: a Post-training Study. Human Resource Development Quarterly, 13, 89-108. http://dx.doi.org/10.1002/hrdq.1015

Moran, E.T., \& Volkwein, J.F. (1992). The cultural approach to the formation of organizational climate. Australian Journal of Communication, 17, 98-112. http://dx.doi.org/10.2307/1252308

Morgan, R.S., \& Hunt, S.D. (1994). The Commitment-trust Theory of Relationship Marketing. Journal of marketing, 58, 20-38.

Morris, M., Lydka, H., \& O'Creevy, M.F. (1993). Can Commitment be Managed? A longitudinal analysis of employee commitment and human resource policies. Human Resource Management Journal, 3, 21-30. http://dx.doi.org/10.1111/j.1748-8583.1993.tb00314.x

Mowday, R. T., Porter, L. W., \& Steers, R. M. (1982). Employee-Organization Linkages, In P. Warr (Ed.), Organizational and occupational psychology, pp. 219-229. New York: Academic Press.

O'Driscoll, M.P., \& Randall, D.M. (1999). Perceived Organizational Support, Satisfaction with Rewards, and Employee Job Involvement and Organizational Commitment. Applied Psychology: An International Review, 48, 197-209.

Ogba, I. (2008). Commitment in the workplace. The Impact of income and age on employee commitment in Nigerian banking sector. Management Research News, 31, 867-878. http://dx.doi.org/10.1108/01409170810913051

Pfeffer, J. (1998). The human equation: Building profits by putting people first. Boston: Harvard Business School Press.

Purang, P. (2008). Dimensions of HRD Climate enhancing organisational commitment in Indian organizations. Indian Journal of Industrial Relations, 43, 528-546.

Rao, T.V., \& Abraham, E. (1990). The HRD Climate Survey, In J.W. Pfeiffer (Ed.). The 1990 annual Developing Human Resources. San Diego, CA: University Associates.

Reichers, A. E., \& Schneider, B. (1990). Climate and Culture: An Evolution of Constructs. In B. Schneider (Ed), Organizational climate and culture (pp. 5-39). San Francisco: Jossey-Bass.

Sampson, W.R. (2005). Influences on Employee Behaviour Part I. [Online] Available: http://www.uwec.edu/Sampsow/350/2005a/PowerPoints/350-05-03-15_files/frame.htm (April 5, 2010).

Sanusi, L.S. (2011). Banks in Nigeria and national economic development - a critical review. Keynote address by Mr Sanusi Lamido Sanusi, Governor of the Central Bank of Nigeria, at the seminar on "Becoming an economic driver while applying banking regulations", organized by the Canadian High Commission in joint collaboration with the Chartered Institute of Bankers of Nigeria (CIBN) and the Royal Bank of Canada (RBC), Lagos, 7 March 2011.

Schein, E. H. (1992). Organizational Culture and Leadership, (2nd ed.). San Francisco, CA: Jossey-Bass.

Sharma, B.R. (1989). A Study of the Relationship of Organisational Climate with Organisational; Commitment 
and Psychological Well being, PhD Thesis, Himachal Pradesh University, Shimla.

Smith, R. L. (1988). Human Resource Development: An overview. ERIC/CAPS, Ann Arbor, Michigan.

Steers, R.M. (1977). Antecedents and Outcomes of Organisational Commitment. Administrative Science Quarterly, 22, 46-56. http://dx.doi.org/10.2307/2391745

Tannenbaum, S.L., Mathieu, J.E., Salas, E., \& Cannon-Bowers, J.A. (1991). Meeting Trainees' Expectations: The Influence of Training Fulfillment on the Development of Commitment, Self-eficacy, and Motivation. The Journal of Applied Psycology, 76, 759-769. http://dx.doi.org/10.1037/0021-9010.76.6.759

Torraco, R., \& Swanson, R. (1996). The Strategic Roles of Human Resource Development. Human Resource Planning, 18, 10-21.

Tracey, J.B., Tannenbaum, S.L., \& St.Kavanaugh, M.J. (1995). Applying Training Skills on the Job: The Importance of Work Environment. Journal of Applied Psychology, 80, 239-252. http://dx.doi.org/10.1037/0021-9010.80.2.239

Ulrich, D. (1998, Jan.-Feb.). A New Mandate for Human Resources. Harvard Business Review, (Jan.-Feb.), 124-133.

Visser, R.C., \& van der Sluis, L.E.C. (2006). Empirical Evidence for Positive Effects of Training and Developmental Opportunities on Work Attitudes of Employees in the Public Sector, Paper presented at the International HRD Conference - The Learning Society for Sustainable Development, Royal Tropical Institute, Amsterdam, Netherlands, 9 - 11 October, 2006.

Wasti, S.A. (2002). Affective and continuance commitment to the organisation: test of an integrated model in the Turkish context. International Journal of Intercultural Relations, 26, 525-50. http://dx.doi.org/10.1016/S0147-1767(02)00032-9

Webster. (1992). New Webster's Dictionary and Thesaurus of the English Language. (Danbury: Lexicon Publications).

Wallace, J., Hunt, J., \& Richards, C. (1996). The Relationship between Organisational Culture, Organisational Climate and Managerial Values: A Proposed Model. Paper presented at ANZAM '96 Diversity \& Change: Challenges for Management into the 21st Century International Conference, Wollongong NSW, December.

Wright, P, M. (1999). What next? Key Findings from the 1999 State-of-the-art Practice Study. Human Resource Planning, 22, 12-20.

Table 1. Mean, Variance Standard Deviation and Pearson Correlation of all Variables

\begin{tabular}{|l|c|c|c|c|c|c|c|c|}
\hline \multicolumn{1}{|c|}{ Scale } & Mean & Variance & SD & HRDC & AC & CC & NC & $\boldsymbol{r}$-sq \\
\hline HRD Climate & 95.45 & 736.806 & 27.1442 & 1.00 & & & & \\
\hline $\begin{array}{l}\text { Affective } \\
\text { Commitment }\end{array}$ & 20.26 & 40.88 & 6.39 & $.745^{*}$ & 1.00 & & & $0.55(55 \%)$ \\
\hline $\begin{array}{l}\text { Continuance } \\
\text { Commitment }\end{array}$ & 26.78 & 50.37 & 7.09 & $.588^{*}$ & $.520^{*}$ & 1.00 & & $0.31(31 \%)$ \\
\hline $\begin{array}{l}\text { Normative } \\
\text { Commitment }\end{array}$ & 16.76 & 22.25 & 4.79 & $.691^{*}$ & $.709^{*}$ & $.687^{*}$ & 1.00 & $0.45(45 \%)$ \\
\hline
\end{tabular}

*Correlation is significant at the 0.01 level (2-tailed) 


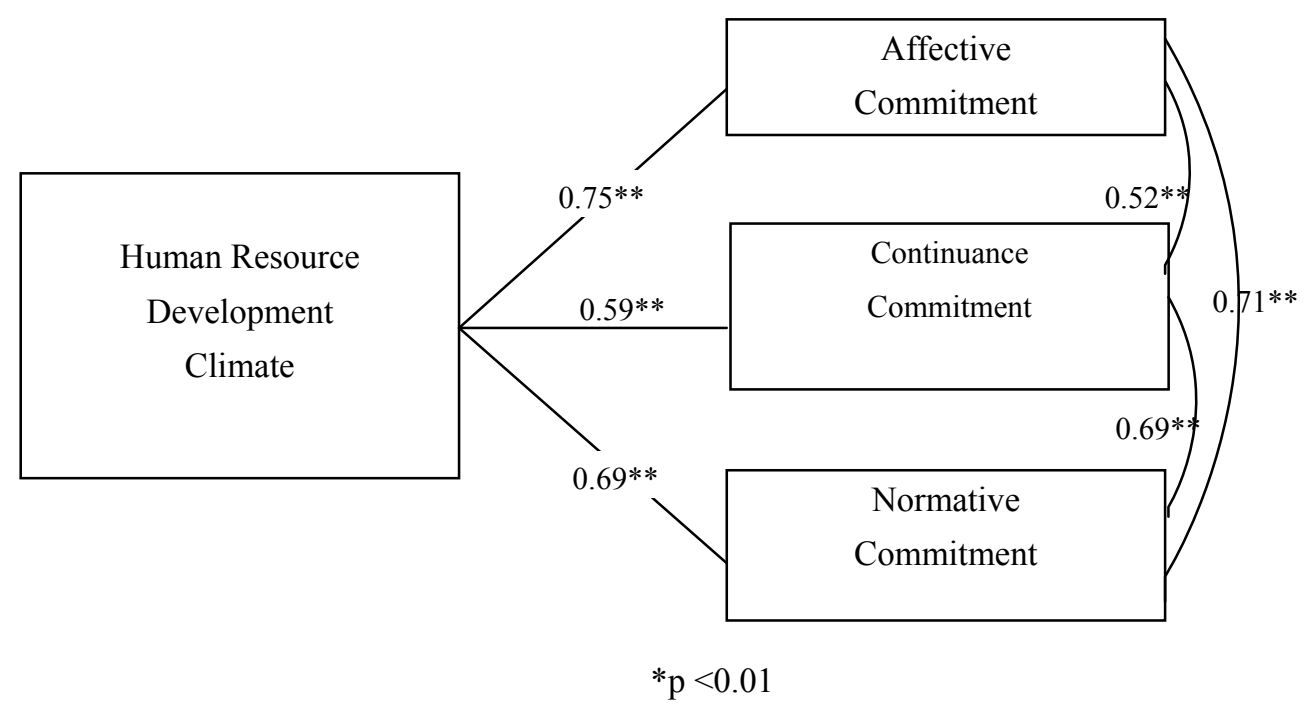

Figure 1. The Influence of HRD Climate on Organizational Commitment 